\title{
Gene action and heritability for photosynthetic activity in two wheat crosses
}

\author{
M.R. Simón \\ Dept. Producción Vegetal, Cerealicultura, Facultad de Ciencias Agrarias y Forestales. Universidad Nacional De \\ La Plata, C.C.31. 1900 La Plata, Argentina \\ Received 25 May 1993; accepted 9 May 1994
}

Key words: Triticum aestivum, wheat, photosynthesis, gene action, heritability

\section{Summary}

Gene action and heritability for photosynthetic activity were estimated from generation means in two wheat crosses during two stages $\left(5^{\text {th }}\right.$ leaf and flag leaf between 2 and 5 days after anthesis). Six generations were available for each cross: parents $\left(\mathrm{P}_{1}\right.$ and $\left.\mathrm{P}_{2}\right), \mathrm{F}_{1}, \mathrm{~F}_{2}$ and backcrosses $\left(\mathrm{BC}_{1}\right.$ and $\left.\mathrm{BC}_{2}\right)$.

Correlations between some morphophysiological characters and photosynthetic activity of the flag leaf was also determined. The joint scaling test described by Mather \& Jinks was used to determine the gene action. It showed that the $\mathrm{m}$; [d]; [h]; [i], [1] (mean, additivity, dominance, additive $\times$ additive interallelic interaction effects, dominance $\times$ dominance interallelic interaction effects) model fits the two crosses at both measurement times. All the model genetic components were significant for the flag leaf, however for the $5^{\text {th }}$ leaf only [h]; [i] and [l] were significant. The presence of additive and additive $x$ additive effects suggested the possibility of selecting for this character using the flag leaf so as to obtain pure inbred lines. Dominance effects [h] were negative and dominance $\times$ dominance effects [1] were positive. Broad sense heritability values were medium to low. There were no correlations between the studied morphophysiological characters and the photosynthetic activity.

\section{Introduction}

Plant breeders have been successful in producing high yielding varieties of wheat crosses. However, the genetic gain in grain yield has been achieved at the expense of straw yield, the total dry matter yields of new varieties being the same as those of the varieties grown during the last century (Austin et al., 1980). Opportunities for making further improvements in grain yield by a continuation of the past trend seem to be limited. In the future, therefore, attention needs to be given to the possibility of increasing the photosynthetic activity of the crop, although it has been reported that selection for this character has not resulted in an increased yield (Nelson, 1988). This could be attributed to lack of genetic variation for photosynthesis capacity among the breeding material or limited exploitation of this capacity by breeders (Austin, 1989). With respect to this point Carver et al. (1989) has demonstrated additive genetic effects. Mahon (1983), reporting results from several authors, also found additive genetic effects in some crops whereas Pukhal'skii et al., (1984) found that the photosynthetic activity was governed by both additive and epistatic genetic effects. Carver et al. (1989) found intermediate heritability values $(0.39)$ for photosynthesis in wheat.

Austin (1989) reported negative correlations between the leaf area and the photosynthesis activity among $T$. aestivum varieties. Rawson et al. (1983) however, indicated that this relation was not always important, whereas Carver et al. (1989) found no significant correlations between leaf area and $\mathrm{CO}_{2}$ assimilation rate in two classes of winter wheat. Differences between photosynthetic activity at both flag leaf stage and vegetative stage have also been found (Rawson et al., 1983).

The aim of this study was to determine the presence of genetic variability for photosynthetic activity, the genetic components of the variance, the heritability of the character and the presence of correlations between photosynthetic activity and some morphophysiological characters related to yield in two T. aestivum $\mathrm{L}$. crosses 
Table 1. Mean values and standard errors for photosynthetic activity in $\mu \mathrm{mol} / \mathrm{m}^{2} \mathrm{~s}$

\begin{tabular}{|c|c|c|c|c|}
\hline & \multicolumn{2}{|c|}{ Pucará $\times$ Chasicó } & \multicolumn{2}{|l|}{ Star $\times$ Ciano } \\
\hline & 5th leaf & flag leaf & 5th leaf & flag leaf \\
\hline P1 & $20.13 \pm 3.82$ & $21.47 \pm 3.66$ & $24.22 \pm 4.12$ & $22.70 \pm 4.00$ \\
\hline P2 & $18.28 \pm 4.88$ & $14.55 \pm 2.65$ & $23.70 \pm 3.38$ & $19.51 \pm 2.58$ \\
\hline $\mathrm{F} 1$ & $20.65 \pm 5.75$ & $23.61 \pm 3.93$ & $26.16 \pm 3.19$ & $20.35 \pm 2.25$ \\
\hline $\mathrm{F} 2$ & $20.92 \pm 6.43$ & $21.53 \pm 2.95$ & $25.78 \pm 4.26$ & $22.97 \pm 3.52$ \\
\hline $\mathrm{BC} 1$ & $18.87 \pm 2.95$ & $21.09 \pm 4.37$ & $21.22 \pm 5.07$ & $21.63 \pm 4.07$ \\
\hline $\mathrm{BC} 2$ & $15.07 \pm 4.37$ & $16.03 \pm 5.05$ & $20.43 \pm 5.47$ & $17.14 \pm 3.36$ \\
\hline
\end{tabular}

between varieties with a different genetic background at two developing stages.

\section{Materials and methods}

$\mathrm{F} 1$ and $\mathrm{F} 2$, as well as backcrosses to each parent (BC1 and BC2) were developed for two Argentinian varieties (Buck Pucará and Chasicó INTA) and two Mexican varieties (Star ' $\mathrm{S}$ ' and Ciano 79). These were grown in a trial field planted in June. Plots were $1 \mathrm{~m}$ long and seeds were planted in rows $4 \mathrm{~cm}$ apart in three replicates. $\mathrm{N}$ and $\mathrm{P}$ fertilizer was applied at sowing and plots were irrigated regularly.

The photosynthetic activity was measured at two stages. Firstly, when there were 5 main stem leaves and then on the flag leaf 2 to 5 days after anthesis. A Li-Cor portable infrared gas analyzer was used. The data was adjusted to a curve to ensure that the irradiances were saturating. Only data above $1300 \mu \mathrm{mol} \cdot \mathrm{m}^{-2} \cdot \mathrm{s}^{-1}$ was considered, because at that point photosynthesis did not increase anymore.

Although the measurements were taken on sunny days, a quartz iodine lamp was used as a light supplement when needed. The temperature remained between 19 and $25^{\circ} \mathrm{C}$ at the time of the measurements and the air humidity between 50 and $60 \%$. Photosynthesis values were expressed in $\mu \mathrm{mol} \mathrm{CO}_{2} \mathrm{~m}^{-2} \mathrm{~s}^{-1}$.

Between 20 to 40 plants per generation and per replication for each cross and time were evaluated. The larger number was used for the segregating generations, the measurements taken in the following way: 5 to 10 leaves were measured per replication per generation for up to 8 days in each developing stage until the required number of plants had been measured on the two crosses. The measurements were taken between 10 am and $2 \mathrm{pm}$.

A generation mean analysis was made using the joint scaling test described by Mather \& Jinks (1977) which estimates the mid-parent, genetic components and digenic interaction genetic components. These estimates were used to fit the data to genetic models. The genetic components consisted of the additive component (d) and the dominance component (h). Interaction components were the additive $x$ additive component (i), the additive $\times$ dominance component (j) and the dominance $\times$ dominance component (1). The goodness of fit for eight different genetic models was tested by estimating $\mathrm{m}$, [d],[h] for a maximum of two interaction components, in order to retain at least one degree of freedom. The fit for the six parameter model could not be tested because of the lack of degree of freedom. The model was considered appropriated if the chi-squared test probability level was 0.05 or greater. Individual genetic components were tested for significance using a Student's 't' test. Genetic components estimated to be different from zero at $\mathrm{P}<0.05$ were considered to contribute to the model.

Broad sense heritability was estimated using Allard's (1960) approach.

$$
\mathrm{h}_{2}=\frac{\sigma^{2} \mathbf{F}_{2}-\left(\sigma^{2} \mathbf{P}_{1}+\sigma^{2} \mathbf{P}_{2}+\sigma^{2} \mathbf{F}_{1}\right) / 3}{\sigma^{2} \mathbf{F}_{2}}
$$

and the standard error of the $h^{2}$ equation

$$
\begin{aligned}
& \mathrm{SEh}^{2}=\left\{1 / 9 * 2 / \sigma^{2} \mathrm{~F}_{2} *\right. \\
& {\left[\left(\frac{\sigma^{2} \mathrm{P}_{1}+\sigma^{2} \mathrm{P}_{2}+\sigma^{2} \mathrm{~F}_{1}}{\mathrm{~d}_{\mathrm{F}} \mathrm{F}_{2}}\right)+\right.} \\
& \left.\left.\left(\frac{\sigma^{2} \mathrm{P}_{1}}{\mathrm{~d}_{\mathrm{F}} \mathrm{P}_{1}}\right)+\left(\frac{\sigma^{2} \mathrm{P}_{2}}{\mathrm{~d}_{\mathrm{F}} \mathrm{P}_{2}}\right)+\left(\frac{\sigma^{2} \mathrm{~F}_{1}}{\mathrm{~d}_{\mathrm{F}} \mathrm{F}_{1}}\right)\right]\right\}
\end{aligned}
$$


df $\mathrm{P}_{1}$; df $\mathrm{P}_{2}$; df $\mathrm{F}_{1}$ and df $\mathrm{F}_{2}=$ Degrees of freedom of the $P_{1} ; P_{2} ; F_{1}$ and $F_{2}$ populations, respectively.

The correlation between photosynthetic activity of the flag leaf and flag leaf area, flag leaf width, flag leaf length and flag leaf duration were estimated. These correlations were made across the six generations of each cross in each block (a total of 36 values) and also within each individual cross (18 values).

Flag leaf area, flag leaf width, flag leaf length and flag leaf duration were determined on 15-20 flag leaves for each cross per generation per replication.

\section{Results}

The mean values and standard errors for photosynthetic activity are shown in Table 1 . In both crosses, during both development stages, the model $m$ [d] [h] [i] [l] best fitted the data.

The goodness of fit to the models for each cross during each development stage and the significance of the genetic components in the appropriated models are given in Table 2 and 3, respectively.

In both crosses for the flag leaf measurement, all the genetic components contributed to the models, whereas at the $5^{t h}$ leaf stage only [h] [i] and [l] contributed to the models. The dominance effect was negative, while the dominance $\times$ dominance effect was positive.

The broad sense heritability values were medium to low. At the 5th leaf stage the values and their standard errors were $42 \% \pm 10$ and $29 \% \pm 12$ for Pucará $\times$ Chasicó and Star $\times$ Ciano, respectively. At the flag leaf stage the values were $38 \% \pm 20$ and $25 \% \pm 13$.

There was no significant correlation between photosynthetic activity of the flag leaf and flag leaf area, leaf width, leaf length nor the flag leaf area duration either between crosses or within each cross.

\section{Discussion}

In the two wheat crosses examined, a model with additive, dominance, additive $x$ additive and dominance $x$ dominance effects gave the best fit to the data for rate of photosynthesis.

Pukhal'skii et al., (1986) found similar results with a preponderance of additive effects and also with epistatic effects. Mahon (1983) and Carver et al., (1989) found a preponderance of additive effects.

There are some differences between the genetic effects at the 5th leaf and flag leaf stage. Rawson et al.,
Table 2. $\chi^{2}$ Goodness of fit test and probability of fit of two crosses at two developing stages for photosynthetic activity, using eight genetic models

\begin{tabular}{|c|c|c|c|}
\hline & Model & $x^{2}$ & $\mathrm{P}$ \\
\hline Pucará $\times$ Chasicó & $\mathrm{m}[\mathrm{d}]$ & 10.69 & $0.05-0.01$ \\
\hline \multirow[t]{7}{*}{ Sth leaf } & $\mathrm{m}[\mathrm{d}][\mathrm{h}]$ & 10.70 & $0.05-0.01$ \\
\hline & $\mathrm{m}[\mathrm{d}][\mathrm{h}][\mathrm{i}]$ & 10.68 & $<0.01$ \\
\hline & $\mathrm{m}[\mathrm{d}][\mathrm{h}][\mathrm{j}]$ & 8.28 & $0.05-0.01$ \\
\hline & $m[d][h][1]$ & 8.13 & $0.05-0.01$ \\
\hline & $\mathrm{m}[\mathrm{d}][\mathrm{h}][\mathrm{i}][\mathrm{j}]$ & 8.25 & $0.05-0.01$ \\
\hline & $\mathrm{m}[\mathrm{d}][\mathrm{h}][\mathrm{i}][\mathrm{l}]$ & 2.23 & $0.25-0.1$ \\
\hline & $\mathrm{m}[\mathrm{d}][\mathrm{h}][\mathrm{j}][1]$ & 5.21 & $0.05-0.01$ \\
\hline Star $\times$ Ciano & $\mathrm{m}[\mathrm{d}]$ & 19.62 & $<0.01$ \\
\hline \multirow[t]{7}{*}{ 5th leaf } & $\mathrm{m}[\mathrm{d}][\mathrm{h}]$ & 16.36 & $<0.01$ \\
\hline & $\mathrm{m}[\mathrm{d}][\mathrm{h}][\mathrm{i}]$ & 134.17 & $<0.01$ \\
\hline & $\mathbf{m}[\mathrm{d}][\mathrm{h}][\mathrm{j}]$ & 16.32 & $<0.01$ \\
\hline & $\mathrm{m}[\mathrm{d}][\mathrm{h}][\mathrm{l}]$ & 13.05 & $<0.01$ \\
\hline & $m[d][h][i][j]$ & 128.24 & $<0.01$ \\
\hline & $\mathrm{m}[\mathrm{d}][\mathrm{h}][\mathrm{i}][\mathrm{I}]$ & 0.06 & $0.9-0.75$ \\
\hline & $\mathrm{m}[\mathrm{d}][\mathrm{h}][\mathrm{j}][\mathrm{l}]$ & 12.91 & $<0.01$ \\
\hline Pucará $\times$ Chasicó & $\mathrm{m}[\mathrm{d}]$ & 30.61 & $<0.01$ \\
\hline \multirow[t]{7}{*}{ flag leaf } & $\mathrm{m}[\mathrm{d}][\mathrm{h}]$ & 10.82 & $0.05-0.01$ \\
\hline & $\mathrm{m}[\mathrm{d}][\mathrm{h}][\mathrm{i}]$ & 10.68 & $<0.01$ \\
\hline & $\mathrm{m}[\mathrm{d}][\mathrm{h}][\mathrm{j}]$ & 10.37 & $<0.01$ \\
\hline & $\mathrm{m}[\mathrm{d}][\mathrm{h}][\mathrm{l}]$ & 7.70 & $0.05-0.01$ \\
\hline & $m[d][h][i][j]$ & 14.49 & $<0.01$ \\
\hline & $\mathrm{m}[\mathrm{d}][\mathrm{h}][\mathrm{i}][\mathrm{l}]$ & 1.48 & $0.25-0.1$ \\
\hline & $m[d][h][i][1]$ & 6.90 & $<0.01$ \\
\hline Star $\times$ Ciano & $\mathrm{m}[\mathrm{d}]$ & 16.73 & $<0.01$ \\
\hline \multirow[t]{7}{*}{ flag leaf } & $m[d][h]$ & 15.41 & $<0.01$ \\
\hline & $\mathrm{m}[\mathrm{d}][\mathrm{h}][\mathrm{i}]$ & 18.52 & $<0.01$ \\
\hline & $m[d][h][j]$ & 29.88 & $<0.01$ \\
\hline & $\mathrm{m}[\mathrm{d}][\mathrm{h}][\mathrm{l}]$ & 14.17 & $<0.01$ \\
\hline & $m[d][h][i][j]$ & 5.14 & $<0.01$ \\
\hline & $\mathrm{m}[\mathrm{d}][\mathrm{h}][\mathrm{i}][\mathrm{l}]$ & 3.72 & $0.1-0.05$ \\
\hline & $\mathrm{m}[\mathrm{d}][\mathrm{h}][\mathrm{i}][\mathrm{l}]$ & 11.18 & $<0.01$ \\
\hline
\end{tabular}

(1983) found no correlation between photosynthesis at the flag leaf stage and the vegetative stages, so the gene expression varies with the development stage. In this study no variation was seen between cultivars in each cross for the 5th leaf measurement. However, there were differences for flag leaf measurement, illustrating the importance of additivity values at this stage. In spite of the differences and considering the importance of the flag leaf for the filling of the grain, these results 
Table 3. Fit of the individual genetic components and standard errors for models with acceptable chi-square fit

\begin{tabular}{|c|c|c|}
\hline & Model & Component fit \\
\hline $\begin{array}{l}\text { Pucará } \times \text { Chasicó } \\
\text { 5th leaf }\end{array}$ & $\mathrm{m}[\mathrm{d}][\mathrm{h}][\mathrm{i}][\mathrm{l}]$ & $\begin{array}{l}d=1.51 \pm 0.78 \\
h=-42.46 \pm 15.6^{*} \\
i=-16.08 \pm 6.59^{*} \\
l=27.95 \pm 9.63^{*}\end{array}$ \\
\hline $\begin{array}{l}\text { Star } \times \text { Ciano } \\
\text { 5th leaf }\end{array}$ & $\mathrm{m}[\mathrm{d}][\mathrm{h}][\mathrm{i}][\mathrm{l}]$ & $\begin{array}{l}\mathrm{d}=0.33 \pm 0.71 \\
\mathrm{~h}=-54.38 \pm 14.4^{* *} \\
\mathrm{i}=-19.82 \pm 5.52^{* *} \\
\mathrm{l}=36.76 \pm 9.12^{* *}\end{array}$ \\
\hline $\begin{array}{l}\text { Pucará } \times \text { Chasicó } \\
\text { flag leaf }\end{array}$ & {$[\mathrm{m}][\mathrm{d}][\mathrm{h}][\mathrm{i}][\mathrm{l}]$} & $\begin{array}{l}\mathrm{d}=3.75 \pm 0.51^{* * *} \\
\mathrm{~h}=-25.06 \pm 10.54^{*} \\
\mathrm{i}=-11.11 \pm 4.48^{*} \\
\mathrm{l}=19.48 \pm 6.45^{* *}\end{array}$ \\
\hline $\begin{array}{l}\text { Star } \times \text { Ciano } \\
\text { flag leaf }\end{array}$ & {$[\mathrm{m}][\mathrm{d}][\mathrm{h}][\mathrm{i}][\mathrm{l}]$} & $\begin{array}{l}\mathrm{d}=2.11 \pm 0.58^{* *} \\
\mathrm{~h}=-39.19 \pm 10.98^{* *} \\
\mathrm{i}=-15.62 \pm 4.51^{* *} \\
\mathrm{l}=22.59 \pm 6.68^{* *}\end{array}$ \\
\hline
\end{tabular}

* Significant $\mathrm{P}<0.05$.

** Significant $P<0.01$.

*** Significant $\mathrm{P}<0.001$.

may be useful for selecting for photosynthetic activity at this stage in order to obtain pure inbred lines.

The significant additive $\times$ additive component also increases the genetic variance in $\mathrm{F}_{2}$ and is fixable by selection. The [h] effect and the [1] effect may also be exploited, but only if hybrid wheat is the objective of the breeding program. In this study the dominance effects were negative. This can produce lower values for $F_{1}$ than for parents. However, the dominance $\times$ dominance effects were positive, so the $F_{1}$ value depended on the relative importance of both effects.

Broad heritability values similar to those found by Carver et al. (1989) were observed. However, it is necessary to consider that according to the presence of dominance and epistatic effects the narrow sense heritability would have had lower values.

Austin (1989) found negative correlations between some morphophysiological characters and the photosynthetic activity among different Triticum aestivum varieties. However, Rawson et al., (1983) pointed out that the negative correlations between leaf area and photosynthetic activity were not always important and Carver et al., (1989) found no such correlation between leaf area and $\mathrm{CO}_{2}$ assimilation rate within two wheat classes (soft and red winter wheat). In this study, the lack of correlations indicate that in some germplasm these negative correlations did not exist. Thus, selection for improved photosynthetic activity could be possible without negative changes in leaf area. Nevertheless, selection for photosynthetic activity in segregating generations is not easy and progress is likely to be slow.

\section{Acknowledgements}

The author thanks Dr. S. Rajaram (CYMMYT) and Buck S.A. Breeder who provided the seed of the Mexican and Argentinian varieties, respectively. Also Ings. Juan José Guiamet, José Beltrano and Sonia Suárez for their assistance. She also thanks the INFIVE (Institute of Plant Physiology, La Plata, Argentina) for having provided the infrared gas analyzer.

\section{References}

Allard, R.W., 1960. Principles of Plant Breeding. John Wiley \& Sons, New York. 485 pp.

Austin, R.B., J. Bingham, R.D. Blackwell, L.T. Evans, M.A. Ford, C.L. Morgan \& M. Taylor, 1980. Genetic improvements in winter wheat. J. Agric. Sci., Camb. 94: 675-689.

Austin, R.B., 1989. Genetic variation in photosynthesis. J. Agric. Sci., Cambr. 112: 287-294.

Carver, B., R.C. Johnson \& A. Lane Rayburn, 1989. Genetic analysis of photosynthesis variation in hexaploid and tetraploid wheat and their interspecific hybrids. Phot. Res. 20: 105-118.

Mahon, J.D., 1983. Limitations to the use of physiological variability in plant breeding. Can. J. Plant Sci. 63: 11-21.

Mather, K. \& J.L. Jinks, 1977. Introduction to biometrical genetics of populations. Vol. 1. The University of Chicago Press, Chicago. 469 pp.

Nelson, C.L., 1988. Genetic associations between photosynthetic characteristics and yield. Review of evidence. Plant Physiol. Biochem. 26: 543-554.

Pukhal'skii, U.A., N.P. Piskunova \& V.K. Gins, 1984. The genetic determination of photochemical activity in leaf chloroplast of spring wheat. Doklady Vsesoyuznoi Ordena Lenina i Ordena Trudovogo Znameni Akademii Sel'skokhozyaistvennykhnavk Imeni V.I. Lenina 7: $2-4$.

Rawson, H.M., J.H. Hindmarsh, R.A. Fischer \& Y.M. Stockman, 1983. Changes in leaf photosynthesis with plant ontogeny and relationships with yield per ear in wheat cultivars and 120 progeny. Aust. J. Plant Physiol. 10: 503-514. 